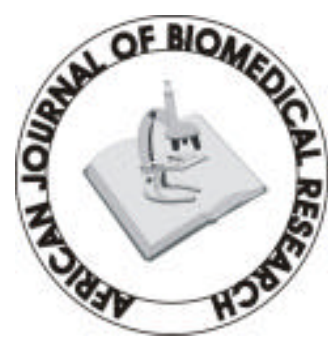

Full-text available at http://www.ajbrui.com

http://www.bioline. $b r / m d$

Received:

August, 2005

Accepted (Revised):

January, 2006

Published

January, 2006
Full Length Research Article

\section{The Relationships between Percent Body Fat and other Anthropometric Nutritional Predictors among Male and Female Children in Nigeria.}

\author{
${ }^{* 1}$ Olabinri B. M; ${ }^{2}$ Olawoye T. L; ${ }^{3}$ Olaleye M. L; ${ }^{4}$ Ajani R. A \\ and ${ }^{5}$ Olorunnisola O.S. \\ 1,4,5 Department of Biochemistry, \\ Ladoke Akintola University of Technology, Ogbomoso Nigeria. \\ ${ }^{2,3}$ Department of Biochemistry, \\ The Federal University of Technology, Akure, Nigeria
}

\section{ABSTRACT}

The relationships between the percent body fat and other nutritional predictors were assessed among forty male and forty female children aged 2 - 10 years. Both sexes were age - matched. There was no significant difference in age between the two groups $(P>0.001)$. A weak significant positive correlation was observed between the percent body fat and height - armspan ratio in female children $(r=0.300 ; P=0.05)$. Height showed a high positive correlation with body's armspan in males ( $r=$ 0.916; $P=0.001)$ Body mass armspan (BMA) correlated positively and significantly with body mass index $(B M I)$ in female $(r=0.922 ; P=0.001)$. The corrected bone-free arm muscle area (AMA) gave positive values in females while two negative values of corrected AMA were observed in males. Mid - upper arm circumference (MUAC) appeared to be a more sensitive predictor of protein - energy malnutrition (PEM) in these children. The mean MUAC was $17.03 \mathrm{~cm}$ in males and $17.0 \mathrm{~cm}$ in females, respectively. There was evidence of overweight and obesity in both children. The mid-arm muscle circumference (MAMC) gave mean value of 14.44 and $13.07 \mathrm{~cm}$ in males and females, respectively. The clinical significance of MUAC, MAMC and corrected AMA measurements are discussed (Afr. J. Biomed. Res. 9: 45 - 52, 2006)

Keywords: body fat, Nutrition, anthropometric, children, Nigeria

*Author for Correspondence: olabinring@yahoo.com 


\section{INTRODUCTION}

Small stature as well as low body weight seems to be more common in developing countries than in developed countries (Norgan, 1990). Reasons for differences have been suggested to have genetic or environmental bases (Forbes, 1988; Durnin, 1989; Norgan; 1990). Furthermore, racial differences in the relationship between body composition and body mass index have been reported (Strickland and Ulijaszek, 1993; Wang el al 1994).

The most important applications of anthropology at field level include biological anthropology, epidemiology, clinical application and metabolic research (Solomons et al 1993). Two anthropometric indices of nutritional status have been reported: body mass index (BMI), weight height squared and body mass armspan (weight/armspan squared) ( Rabe et al 1996; Taylor et al 1996; Tayie et al 2003). Height - armspan ratio racial difference has been reported too (Steele and Maltox, 1987). Armspan looks promising as substitute for height in elderly persons and other whose height cannot be obtained (Tayie et al 2003).

Protein - energy malnutrition (PEM) is the most widespread form of malnutrition in the world today, affecting over 500 million children (WHO, 1990), Protein energy malnutrition and obesity are hazardous to health wit high morbidity and morality rates (Tanphachitr and Leelahagul, 1995). The assessment of body composition is essential to prevent, diagnose and determine the severity of these disorders as well as their response to therapy ( Tanphachitr and Leelahagul, 1995).

The association between percent body fat and other nutritionally parameters -mid - upper arm circumference (MUAC), mid - arm muscle circumference (MAMC) body mass armspan (BMA), body mass index (BMI),tricep skinfold thickness, height-armspan ratio has not been reported in male and female children resident in Nigeria. Also, most reports published internationally focused on the association between armspan and height, body mass index and body mass armspan (Rabe et al 1996; Tayie el al 2003). However, there is no report of the association between percent body fat and other anthropometric nutritional predictors in the population under study hitherto. The objectives of the present study were to assess in Nigeria, the association between percent body fat and corrected AMA, and to test the hypothesis that height correlates positively with armspan using samples of male and female children aged $2-10$ yrs in Ogbomoso, Nigeria.

\section{MATERIALS AND METHODS}

\section{Study population and sampling technique}

Forty male and female Yoruba children aged $2-10$ years participated in the study after informed consent from their parents/ guardians. 80 samples used for this study were from Adiatu, Isale general and Takie areas of Ogbomoso, Oyo State, Nigeria. Ogbomoso is the second largest city in Oyo State,Nigeria. The samples were collected between 10th January and 28th February, 2005.

\section{Anthropometric measurement.}

The height and weight of all the respondents were measured to the nearest $\mathrm{cm}$ and $\mathrm{kg}$ respectively according to standard procedures (Whitney et al 1998) . Body's armspan was measured in the same position as the height, but whit extended arms in a $90^{\circ}$ angle to the body using flexible tape ( Rabe et al 1996). Body's armspan was measured across the chest from the longest finger of the left hand to the middle finger of the right hand. Total length of the out - stretched arms was measured as armspan. Body mass armspan (BMA) was computed from armspan using the formula (weight/armspan squared) (Rabe et al 1996) while body mass index (BMI) was calculated by dividing weight by height - squared (weight /height squared) (Taylor et al 1996).

Mid - upper arm circumference (MUAC) was measured to the nearest $\mathrm{cm}$ using a tape with the left arm hanging relaxed (Marks et al 1989). The measurement of MUAC was taken midway between the tip of acromion and olecranon process. Mid arm muscle circumference (MAMC) was calculated from MUAC using the formula (Chumlea et al 1998).

$M A M C=\operatorname{MUAC}(\mathrm{cm})-3.142 \times \operatorname{TSF}(\mathrm{cm})$,

where TSF is tricep skinfold thickness in $\mathrm{cm}$. The corrected bone - free arm muscle area (AMA) for males was calculated using the corrected bone - free arm muscle area modeling equation reported previously (Schmidt et al 1992).

$$
\begin{aligned}
& \text { Corrected male AMA } \\
& \quad=\frac{\left.[M U A C(\mathrm{~cm})]-3.142 \times \operatorname{TSF}(\mathrm{cm})^{2}\right]-10}{4 \times 3.142}
\end{aligned}
$$

The corrected bone - free arm muscle area (AMA) for female was calculated using a corrected AMA modeling equation (Schmidt et al 1992).

\section{Corrected female AMA

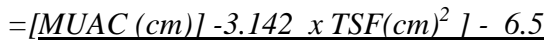 $4 \times 3.142$}

The bicep and tricep skinfold thickness were measured to the nearest mm using a vernier caliper (Holtain Ltd, UK) using the standard procedures (Moore and Dalley 1999 and Taylor et al 1996), respectively. The sum of bicep and tricep skinfold thickness was inserted into the Durnin and Rahaman's percent body fat modeling equation (Durnin and Rahaman, 1967) to compute the percent body fat for 
each child.

Percent body fat $=$

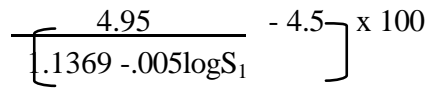

Protein - energy malnutrition was assessed in each child using UNICEF - Brasilia - arm circumference strip reported by Seireg (1989) and WHO (1995). The MUAC value of a well nourished child is above $13.5 \mathrm{~cm}$. MUAC value between 12 and $13.5 \mathrm{~cm}$ indicates malnutrition and below $12 \mathrm{~cm}$ indicates more severe malnutrition.

\section{Statistical Analysis}

Student's t- test was used for statistical analysis. t-value less than $0.05,0.01,0.1$ or 0.001 was considered significant.

\section{RESULTS}

The mean body mass index (BMI) and body mass armspan (BMA) were $16.63 \pm 4.42(\mathrm{SD}) \mathrm{kg} / \mathrm{m}^{2}$ and $16.03 \pm 3.86$ (SD) $\mathrm{kg} / \mathrm{m}^{2}$ in female children, respectively. There was no significant difference $(\mathrm{P}>0.001)$ between the two nutritional predictors. The mean value for BMI in male children was $16.66 \pm 2.89$ (SD) $\mathrm{kg} / \mathrm{m}^{2}$ while the mean BMA gave $15.97 \pm 2.68(\mathrm{SD}) \mathrm{kg} / \mathrm{m}^{2}$ as shown in table 1 . There was no significant difference between the mean BMI and the mean BMA in male children ( $\mathrm{P}>0.001)$. The mean BMA$\mathrm{BMI}$ ratio gave $0.97 \pm 0.18(\mathrm{SD})$ in males, and $0.97 \pm 0.10$ (SD) in females.

There was no significant difference between the mean BMA - BMI ratio in both sexes $(\mathrm{P}>0.001)$..The mean height - armspan ratio was $0.96 \pm 0.05(\mathrm{SD})$ in males and $0.98 \pm 0.04(\mathrm{SD})$ in females. There was a significant difference between height - armspan ratio in both sexes $(\mathrm{P}<0.001)$. Height closely approximates armspan in male children from Ogbomoso, Nigeria as evidenced by a high positive significant positive correlation between height and body's armspan $(=0.916 ; \mathrm{P}=0.001)$ as shown in table 2. The observed association was gender specific.

A high positive significant positive correlation was observed between height and armspan in male children ( $\mathrm{r}$ $=0.916 ; \mathrm{P}=0.001$ ) as shown in table 2 . Similarly, the mean female height showed a high positive significant correlation with body's armspan $(r=0.0970 ; \mathrm{P}=0.001)$ as shown in table 2 .

A weak significant positive correlation was found between body mass index (BMI) and body mass armspan (BMA) ( $\mathrm{r}=0.379 ; \mathrm{P}=0.05)$ among male children in Ogbomoso,A significant high positive correlation was found between body mass index(BMI) and body mass armspan (BMA) among female children in Ogbomoso. ( $\mathrm{r}=$ $0.922 ; \mathrm{P}=0.001)$ and the association was gender specific.

A high significant positive correlation was observed between BMA and BMI in female children and the association was gender specific. All the male children investigated did not possess protein - energy malnutrition (PEM) while three female children had PEM with MUAC value of 13,13 and $13.5 \mathrm{~cm}$ as shown in table 3.A MUAC value above $13.5 \mathrm{~cm}$ is normal for children (WHO, 1995) from 15 years of age. The MUAC value of a well nourished child is above $13.5 \mathrm{~cm}$.MUAC values between 12 and $13.5 \mathrm{~cm}$ indicates malnutrition and below 12 indicates more severe malnutrition (WHO, 1995). UNICEF - Brasilia - arm circumference strip currently in use in Nicaragua as reported by Seireg 1989, has the following age specific cut - off points for defining malnutrition: 0-1 month, $9 \mathrm{~cm} ; 2-5$ months, $10.5 \mathrm{~cm} ; 6-30$ months, $12.5 \mathrm{~cm}$ and 31-60 months. The value of $13.5 \mathrm{~cm}$ was used to assess PEM in these children in addition to WHO indicator for PEM.

Table 1

Some physical parameters of male and female children in Ogbomoso, Nigeria

\begin{tabular}{lll}
\hline Parameter & $\begin{array}{l}\text { Male }(\mathbf{2 - 1 0 y r s}) \\
\mathbf{n}=\mathbf{4 0}\end{array}$ & $\begin{array}{l}\text { Female(2- 10 yrs) } \\
\mathbf{n}=\mathbf{4 0}\end{array}$ \\
\hline Mean age $\pm \mathrm{SD}(\mathrm{yrs})$ & $6.35 \pm 2.97$ & $6.28 \pm 2.93$ \\
\hline Height $\pm \mathrm{SD}(\mathrm{cm})$ & $110.99 \pm 16.51$ & $111.34 \pm 16.66$ \\
\hline $\begin{array}{l}\text { Height}- \text { armspan ratio } \\
\pm \mathrm{SD}(\mathrm{cm})\end{array}$ & $0.96 \pm 0.05$ & $0.98 \pm 0.04$ \\
\hline Weight $\pm \mathrm{SD}\left(\mathrm{kg} / \mathrm{m}^{2}\right)$ & $20.66 \pm 5.50$ & $20.53 \pm 5.68$ \\
\hline $\begin{array}{l}\text { Body mass index } \\
\pm \mathrm{SD}\left(\mathrm{kg} / \mathrm{m}^{2}\right)\end{array}$ & $16.66 \pm 2.89$ & $16.63 . \pm 4.42$ \\
\hline $\begin{array}{l}\text { Body mass armspan } \\
\pm \mathrm{SD}\left(\mathrm{kg} / \mathrm{m}^{2}\right)\end{array}$ & $15.97 \pm 2.68$ & $16.03 \pm 3.86$ \\
\hline BMA $/ \mathrm{BMI}$ ratio $\pm \mathrm{SD}$ & $0.97 \pm 0.18$ & $0.97 \pm 0.10$ \\
\hline
\end{tabular}

Table 2

Pearson's correlations between height and armspan, and between body mass index and body mass armspan of children in Ogbomoso.

\begin{tabular}{lll}
\hline Sex & $\begin{array}{l}\text { Correlation between } \\
\text { height and armspan }\end{array}$ & $\begin{array}{l}\text { Correlation between } \\
\text { body mass index } \\
\text { and body mass } \\
\text { armspan }\end{array}$ \\
\hline Male & $\mathrm{r}=0.916 ;$ & $\mathrm{r}=0.379 ;$ \\
$(\mathbf{2 - 1 0}$ yrs) & $\mathrm{P}=0.001 ; \mathrm{SG}$ & $\mathrm{P}=0.05 ; \mathrm{SG}$ \\
\hline Female & $\mathrm{r}=0.970 ;$ & $\mathrm{r}=0.922 ;$ \\
$(\mathbf{2}-\mathbf{1 0}$ yrs $)$ & $\mathrm{P}=0.001 ; \mathrm{SG}$ & $\mathrm{P}=0.001 ; \mathrm{SG}$ \\
\hline
\end{tabular}

.SG indicates significant.

The mean mid - upper arm circumference were 17.03 \pm 1.92 (SD) and 17.08 2.90 (SD) $\mathrm{cm}$ in male and female children, respectively as shown in table 4 . There was no significant difference between the mean mid - upper farm 
circumference in both sexes ( $\mathrm{P}>0.001)$. The mean corrected bone - free arm muscle area was slightly higher in female than in males and difference was not significant
( $\mathrm{P}>0.001)$. The mean percent body fat was slightly higher in females than males and difference was not significant $(\mathrm{P}>0.001)$

Table 3:

Mid - upper arm circumference (MUAC) distribution by age among 40 male and 40 female children in Ogbomoso, Nigeria.

\begin{tabular}{|l|l|l|l|l|}
\hline Age & \multicolumn{2}{|l|}{ Male ( 2 - 10 yrs) } & Female (2-10yrs) \\
\hline & MUAC distribution in cm & Mean MUAC (cm) & MUAC distribution in cm & Mean MUAC (cm) \\
\hline 2. & $14,14,15,15$ & $14,50 \pm 0.71$ & $13,13.5,14$ & $13.50 \pm 0.71$ \\
\hline 3 & 14,15 & $14.50 \pm 0.71$ & $13,14,15,16,16,16$ & $15.00 \pm 1.10$ \\
\hline 4. & $15,15,15,16,16.5,17$ & $15.75 \pm 1.03$ & $14,15,15$ & $14.67 \pm 0.58$ \\
\hline 5. & $17,17,17,18,18$ & $17,40 \pm 0.55$ & $15,16,16$ & $15.67 \pm 0.58$ \\
\hline 6. & 15,16 & $15.50 \pm 0.71$ & $16,16,16,18,18$ & $16.80 \pm 1.25$ \\
\hline 7. & $16,5,17,17,17,18,19$ & $17,42 \pm 0.92$ & $15,17,17,17,19.9,23$ & $17.90 \pm 2.63$ \\
\hline 8. & $16,16,17,21$ & $17.50 \pm 2.38$ & $16,16.5$ & $16.25 \pm 0.35$ \\
\hline 9. & $17,18,18,18,19$ & $18.00 \pm 0.71$ & $17,18,22,23,25$ & $21,00 \pm 1.87$ \\
\hline 10. & $17,18,18,19,21,23$ & $19.33 \pm 1.55$ & $14,17,18,21,21,22$ & $18.83 \pm 2.00$ \\
\hline
\end{tabular}

\section{Table 4.}

The mean percent body fat, corrected bone - free arm muscle area , mid - upper arm circumference and mid arm muscle circumference for male and female children in Ogbomoso, Nigeria

\begin{tabular}{|c|c|c|}
\hline Parameter & $\begin{array}{l}\text { Male } \\
(2-10 y r s) \\
n=40\end{array}$ & $\begin{array}{l}\text { Female } \\
(2-10 \mathrm{yrs}) \\
\mathrm{n}=40\end{array}$ \\
\hline Percent body fat $\% \pm$ SD & $\begin{array}{l}13.34 \\
\pm 3.01 \\
\end{array}$ & $\begin{array}{l}16.88 \\
\pm 4.03 \\
\end{array}$ \\
\hline $\begin{array}{l}\text { Mid - upper arm circumference } \\
(\text { MUAC) } \mathrm{cm} \pm \mathrm{SD}\end{array}$ & $\begin{array}{l}17.03 \\
\pm 1.92 \\
\end{array}$ & $\begin{array}{l}17.08 \\
\pm 2.90 \\
\end{array}$ \\
\hline $\begin{array}{l}\text { Corrected bone }- \text { free arm } \\
\text { muscle area (AMA) }\left(\mathrm{cm}^{2}\right) \pm S D\end{array}$ & $\begin{array}{l}6.47 \\
\pm 5.17 \\
\end{array}$ & $\begin{array}{l}7.42 \\
\pm 4.41 \\
\end{array}$ \\
\hline $\begin{array}{l}\text { Triceps skinfold thickness }(\mathrm{cm}) \\
\pm \text { SD }\end{array}$ & $\begin{array}{l}0.88 \\
\pm 0.24 \\
\end{array}$ & $\begin{array}{l}1.28 \\
\pm 0.49 \\
\end{array}$ \\
\hline $\begin{array}{l}\text { Range for correct bone - free } \\
\text { arm muscle area }\left(\mathrm{cm}^{2}\right)\end{array}$ & $\begin{array}{l}-2.09 \\
-22.37\end{array}$ & $\begin{array}{l}1.03 \\
-19.53\end{array}$ \\
\hline
\end{tabular}

The mean mid - upper arm circumference ranged from 14.00 to $23.00 \mathrm{~cm}$, and from 13.00 to $25.00 \mathrm{~cm}$ in males and females, respectively while the corrected bone - free arm muscle area ranged from 10.3 to $19.53 \mathrm{~cm}^{2}$, and from -2.09 to $22.37 \mathrm{~cm}^{2}$ females and males respectively.

Corrected bone - free arm muscle area for male

$$
=\frac{\operatorname{MUAC}(\mathrm{cm})-3.142 \times \operatorname{TSF}(\mathrm{cm})-10}{12.57}
$$

Two negative values (-2.09 and - 0.07) were obtained for the correct bone free arm muscle are (AMA) out of the forty male samples analyzed. The two negative values were obtained under certain conditions in males children. The first value of corrected AMA was obtained when the tricep skinfold thickness and mid - upper arm circumference (MUAC) were $1.6 \mathrm{~cm}$ and $15 \mathrm{~cm}$, respectively in male. The second negative value was obtained when the tricep skinfold thickness and mid upper arm circumference were 0.9 and $14 \mathrm{~cm}$, respectively. $\%$ error for corrected AMA in male $=2 / 40 \times 100=5 \%$ Percentage error provides evidence for the limitation of the modeling equation adopted for predicting the value of corrected AMA in male Yoruba children. The widely accepted equation adopted (Schmidt et al 1992) was not a perfect model for the ethnic group studied (male Yoruba children). On the other hand, the modeling equation adopted for predicting corrected AMA gave positive values in female at all values of tricep skinfold thickness and mid - upper arm circumference. This provides over whelming evidence for the suitability of the model adopted in predicting corrected AMA in female children studied. These results are presented in table 5 .

\section{Table 5}

Two negative values obtained for corrected bone - free arm muscle area (AMA) out of the forty male children in Ogbomoso as predicted by the corrected bone - freemass muscle area modeling equation adopted.

\begin{tabular}{ll}
\hline Parameter & $\begin{array}{l}\text { Value of corrected bone - } \\
\text { free arm muscle area }\left(\mathrm{cm}^{2}\right)\end{array}$ \\
\hline Tricep skinfold thickness $(1.6 \mathrm{~cm})$ & -2.09 \\
Mid upper arm circumference & \\
$(15 \mathrm{~cm})$ & \\
\hline Tricep skinfold thickness $(0.9 \mathrm{~cm})$ & -0.07 \\
Mid $\quad$ apper & \\
circumference $(14 \mathrm{~cm})$ & \\
\hline
\end{tabular}


The percentage fat showed a high significant correlation with tricep skinfold thickness in both male and female children who are Yoruba descent $(\mathrm{r}=0.857 ; \mathrm{P}=0.01$ SIG for males; $r=0.929, P=0.01 \mathrm{SG}$ for females).

Percent body fat showed a weak positive correlation with body mass index in female children which was not significant $(\mathrm{r}=0.232 ; \mathrm{P}=0.05)$. The percent body fat correlated positively with height - armspan ratio in females.

\section{Table 6:}

Pearson's correlation between percent body fat and other anthropometric variables in male and female children in Ogbomoso.

\begin{tabular}{|c|c|c|}
\hline Parameter & $\begin{array}{l}\text { Male } \\
(2-10 y r s) \\
n=40 \\
\text { Percent body fat }\end{array}$ & $\begin{array}{l}\text { Female }) \\
n= \\
(2-10 y r s 40 \\
\text { Percent body fat }\end{array}$ \\
\hline $\begin{array}{l}\text { Height - armspan } \\
\text { ratio }\end{array}$ & $\begin{array}{l}\mathrm{r}=-0.236 \mathrm{P}=0.5 \\
; \mathrm{SIG}\end{array}$ & $\begin{array}{l}\mathrm{r}=0.300 \mathrm{P}= \\
0.05 ; \mathrm{SG}\end{array}$ \\
\hline $\begin{array}{l}\text { Body mass index } \\
(\mathrm{BMI})\end{array}$ & $\begin{array}{l}\mathrm{r}=0.092 \mathrm{P}=0.5 \\
\mathrm{NS}\end{array}$ & $\begin{array}{l}\mathrm{r}=0.232 \mathrm{P}= \\
0.05 ; \mathrm{NS}\end{array}$ \\
\hline $\begin{array}{l}\text { Body mass armspan } \\
\text { (BMA) }\end{array}$ & $\begin{array}{l}r=-0.261 \quad P= \\
0.1 ; \mathrm{SG}\end{array}$ & $\begin{array}{l}\mathrm{r}=0.117 \quad \mathrm{P}= \\
0.5 ; \mathrm{SG}\end{array}$ \\
\hline $\begin{array}{ll}\text { Tricep } & \text { skinfold } \\
\text { thickness } & \\
\end{array}$ & $\begin{array}{l}\mathrm{r}=0.857 \quad \mathrm{P}= \\
0.01 ; \mathrm{SG}\end{array}$ & $\begin{array}{l}\mathrm{r}=0.929 \mathrm{P}=0.01 \\
; \mathrm{SG}\end{array}$ \\
\hline $\begin{array}{l}\text { Mid upper arm } \\
\text { circumference } \\
(\text { MUAC) }\end{array}$ & $\begin{array}{l}\mathrm{r}=-0.0333 \\
\mathrm{P}=0.5 ; \mathrm{NS}\end{array}$ & $\begin{array}{l}\mathrm{r}={ }^{-0.636} \\
\mathrm{P}=0.01 ; \mathrm{SG}\end{array}$ \\
\hline $\begin{array}{l}\text { Mid - upper muscle } \\
\text { circumference } \\
\text { (MAMC) }\end{array}$ & $\begin{array}{l}\mathrm{r}=-0.305 \mathrm{P}= \\
0.05 ; \mathrm{SG}\end{array}$ & $\begin{array}{l}\mathrm{r}=0.199 \mathrm{P}=0.01 \\
\mathrm{SG}\end{array}$ \\
\hline $\begin{array}{l}\text { Corrected bone }- \text { free } \\
\text { arm muscle } \\
\text { areamu(AMA) }\end{array}$ & $\begin{array}{l}\mathrm{r}=-0.302 \mathrm{P}= \\
0.05 ; \mathrm{SG}\end{array}$ & $\begin{array}{l}\mathrm{r}=-0.244 \mathrm{P}= \\
0.5 ; \mathrm{SG}\end{array}$ \\
\hline
\end{tabular}

SG indicates significant: NS indicates not significant.
Though the association was weak and significant $(\mathrm{r}=$ 0.300; $\mathrm{P}=0.05$ ) whereas the percent body fat was negatively correlated with height - armspan ratio in male children $(\mathrm{r}=-0.236 ; \mathrm{P}=0.5)$ and the observed association was significant.

The percent body fat correlated positively with body mass armspan, though the association was weak and significant $(r=0.300 ; P=0.05)$ whereas the percent body fat was negatively correlated with body mass armspan in male children $(r=0.261=0.1)$ and the association was significant.

Of special interest is the fact that percent fat correlated positively with MUAC $(r=0.636$; $p=0.01$ in females), the association was high and significant. On other hand, the percent body fat correlated negatively $(\mathrm{r}=-$ $0.0333 ; \mathrm{p}=0.5$ ) with MUAC in male children and the association was not significant..Percent body fat correlated

positively and significantly, though weakly, with MAMC, and corrected AMA in female children $(\mathrm{r}=0.199 ; \mathrm{P}=0.01$ for MAMC; $r=0,244 ; p=0.5$ for corrected AMA). The reverse was true for male children, percent body fat was negatively correlated with MAMC, and AMA ( $\mathrm{r}=-0305$; $\mathrm{P}=0.05$ for MAMC; $\mathrm{r}=-0.302, \mathrm{P}=0.05$ for AMA), and the association was significant.

The Criteria used for predicting overweight and obese children were based on BMI standards reported for children by Cole et al (2000).Seven male children were found to be overweighed while four male children were found to be obese as shown in table 7. On the other hand, two female children were found to be overweighed and five female were found to obese in the present study.

Table 7

Age - specific distribution of underweight and obese children in Ogbomoso based on BMI $\left(\mathrm{kg} / \mathrm{m}^{2}\right)$ sample of $40 \mathrm{male}$ and 40 female children.

\begin{tabular}{|l|l|l|l|l|}
\hline $\begin{array}{l}\text { Age } \\
\text { (yrs) }\end{array}$ & $\begin{array}{l}\text { Distribution of overweight } \\
\text { male children }\end{array}$ & $\begin{array}{l}\text { Distribution of obese } \\
\text { male children }\end{array}$ & $\begin{array}{l}\text { Distribution of overweight } \\
\text { female children }\end{array}$ & $\begin{array}{l}\text { Distribution of obese } \\
\text { female }\end{array}$ \\
\hline 2. & $19.27,1887,19.66$ & Nil & Nil & 20.66 \\
\hline 3. & Nil & 19.81 & Nil & 22.43 .20 .37 \\
\hline 4. & 17.73 & 24.51 & Nil & Nil \\
\hline 5. & 17.53 & 20.62 & Nil & Nil \\
\hline 6. & 18.26 & Nil & 18.62 & Nil \\
\hline 7. & Nil & Nil & 20.14 & 35.56 \\
\hline 8 & Nil & Nil & Nil & Nil \\
\hline 9. & Nil & 24.04 & $24.04 i$ & Nil \\
\hline 10. & 22.76 & Nil & Nil & 24.79 \\
\hline
\end{tabular}




\section{DISCUSSION}

Pearson's correlation yielded subtle differences between percent body and other nutritional predictors, in the present study, among male and female children from Ogbomoso, Nigeria. This study provides robust evidence, for the first time, that a high significant positive correlation exists between percent body fat and MUAC $(\mathrm{r}=$ 0,$63 ; \mathrm{p}=0.01$ ) in female children aged $2-10 \mathrm{yrs}$. This study also demonstrates unequivocally, for the first time, that a high significant positive correlation exists between percent boy fat and tricep skinfold thickness in both male and female children resident in Ogbomoso, Nigeria $(\mathrm{r}=$ $0.857 ; \mathrm{P}=0.01$ in male and $\mathrm{r}=0.929 ; \mathrm{P}=0.01$ in female ( and this may explain why percent body fat in females was higher in female children than male children).

The mean MUAC value was similar in both sexes in the present study. MUAC is a useful index of the efficacy of nutrition therapy in protein - energy malnutrition (PEM) and obesity, where preservation of muscle is a consideration.

In clinical setting, MUAC gives an indication of the body muscle mass and hence its somatic protein status. The measurement of MUAC can now be regarded as a screening method for underweight (normally assessed from the BMI) to identify the preferential loss of peripheral tissue stores of fat and protein (Ferro - Luzzi and James, 1996). BMI and MUAC are sometimes used in conjunction to classify adult nutritional status( James et al 1994). A MUAC value $<18.5 \mathrm{~cm}$ may be indicative of acute under nutrition and MUAC value $16.0 \mathrm{~cm}$ of severe nutrition (James et al 1994) Grade 4 malnutrition is now specified for those with a MUAC $<200 \mathrm{~mm}$ for men and < $190 \mathrm{~mm}$ for women since these MUAC values correspond to the loss of fat stores at BMI of $<13 \mathrm{~kg} / \mathrm{m}^{2}$. (Ferro - Luzzi and James, 1996). Extreme wasting (grade 5 malnutrition ) corresponds to MUAC of 170 and $169 \mathrm{~mm}$ for men and women, respectively (Ferro - Luzzi and James, 1996).

MUAC $(\mathrm{cm})$ is a measure of both energy deficiency in adults and children. Based on mid - term review of World Bank, severe malnutrition with MUAC value $<12.5 \mathrm{~cm}$ for 24 months has been reported. A MUAC value above 13.5 $\mathrm{cm}$ is normal (WHO, 1995) for children from one to 5 years of age. MUAC value between 12 and $13.5 \mathrm{~cm}$ indicates malnutrition and below $12 \mathrm{~cm}$ indicates more severe malnutrition (WHO, 1995). The fact that the mean MUAC was above $13.5 \mathrm{~cm}$ in all the female children examined within the age range (2- 5 years) indicates that PEM was uncommon in these children. However, 3 female children had PEM based on WHO (1995) indicator, and UNICEF Brasilia - arm circumference strip (Seireg, 1989) for PEM.

Accurate interpretations of anthropometric measurement are confounded by problems with the standards used for comparison (Whitney et al 1998). Another limitation of anthropometrics is their inability to describe small changes in body composition that occur over short periods of time (Whitney el al 1998).

A more accurate assessment of muscle mass is obtained by estimating bone - free arm muscle area (Schmidt et al 1992). Anthropometric measures of skeletal muscle mass are indirect assessment of muscles protein. Approximately $60 \%$ of the total body protein is in skeletal muscle - the body's primary source of amino acids (Chumlea et al 1998). AMA estimate may be inaccurate in obese and elderly subjects (Manson et al 1995). In the present study, the corrected AMA gave positive values for female children while two negative values of corrected AMA were obtained for male children from Ogbomoso, Nigeria.

This observation indicates the limitation of the widely used corrected AMA modeling equation reported elsewhere (Schmidt et al 1992), for male children of Yoruba ethnic group studied and suitability of corrected AMA in female children from Ogbomoso, Nigeria who are also of Yoruba descent, and suitability of corrected AMA modeling equation reported by the same investigator for female Yoruba children from Ogbomoso, Nigeria.

Armspan looks promising as a substitute for height in elderly persons and others whose height cannot be obtained (Tayie et al 2003). Also, the present study provides over whelming evidence, for the first time, that a high positive significant correlation exists between height and armspan in female children in Ogbomoso. This finding is in agreement with previous study of Torres et al (2003) who found a high significant correlation between standing height and armspan in children.

More interestingly, the present study, also provides a compelling evidence, for the first time, that body mass index (BMI) correlates positively and significantly with body mass armspan (BMA) in female children age $2-10$ yrs resident in Ogbomoso, Nigeria as confirmed by a high value of $\mathrm{r}(\mathrm{r}=0.992 ; \mathrm{P}=0.001)$ in female children. This finding is consistent with the report of Rabe et al (1996) who found a strong correlation between BMA and BMI in elderly female Indonesians.

In the present study, the mean armspan to height ratio for male and female children were 1.04 and 1.02 respectively. These are similar to those reported by Tayie et al (2003) for elderly male and female Ghanians (1.07 and 1.06 , respectively). The present study also provides robust evidence, for the first time, that armspan - height ratio for male and female children from Ogbomoso, Nigeria were 1.04 and 1.02 unit, respectively, and which differed by 0.02 unit difference whereas the difference between 
armspan - height ratio in elderly male and female Ghanaians differed by 0.01 unit( Tayie et al 2003).

BMI is accepted as in index of obesity 'adiposity in adults (Garrow and Webster, 1985) while the usefulness of body mass index for defining obesity in children is not clear hitherto. Body mass armspan is little known, nor accepted. It was a decay in the elderly where weighter is. When an accurate determination of standing height cannot be obtained ,armspan could be used interchangeably (Torres et al 2003).

Skinfold anthropometry is a well established clinical method for measuring body fat (Alpers et al 1995). BMI is highly correlated with body fat $(0.7-0.8)$ (Wormersley and Durnin, 1977). There is no robust evidence for deciding on cut - offs for obesity in children. The problem of epidemiological definition of obesity in children remains under debate However, in adults, BMI standards are clear. A BMI value greater then $25 \mathrm{~kg} / \mathrm{m}^{2}$ indicates overweight, a BMI value between $18.5-25.00 \mathrm{~kg} / \mathrm{m}^{2}$ indicates the normal healthy limit (WHO, 1990). Most studies show increased mortality in the leanest as well as the most obese individuals (Rissanen, et al 1989; Goldstein ,1992).

Cole et al (2000) reported age -specific BMI standards for defining obesity and overweighed in children The present study found seven male children from Ogbomoso,Nigeria to be overweighed and four to be obese children based on BMI guidelines(Cole et al 2000) for defining obesity and overweight in children.

The paediatrician's role in managing obesity needs clarifying, particular in the context that any recommendations for identification, investigation and treatment have enormous financial and service implications.

\section{REFERENCES}

Alpers DH; Stenson WF and Bier (1995). Obesity . in Alpers DH; Stenson WF and Bier DM (eds). Manual of Nutritional Therapeutics. Little and Brown Company, Massachusetts, USA; ppl -613.

Chumlea WC;Go SS and Vella B (1998). Assessment of protein calorie nutrition. In : Kopple JD and Massry SG (eds) . Nutritional Management of Renal Disease, Baltimore, Williams and Wilkins; pp 203 - 228

Cole TJ: Bellizzi MC: Flegal KM and Dietz WH (2000). Establishing a standard definition for child overweight and obesity worldwide: international survey. B MJ 320(7244):1240-3

During JVGA (1989). Anthropometric methods of assessing nutritional status. In: Horwitz A [ed]. Nutrition in the elderly. Oxford University Press, Oxford; pp 15-32

Durnin JVGA and Rahaman MM( 1967). The assessment of the amount of fat in the human body from measurement of skinfold thickness. Br. J. Nutr.4(1): 23-24.

Ferrozo- Luzzi A and James WP (1996). Adult malnutrition:simple techniques for use in emergencies. Br.J. Nutr: 75 (1): 3 - 10.

Forbes GB (1988).Body composition. Influence of nutrition, disease, growth and ageing. In: Shills ME and Young VR\{eds\}. Modern Nutrition in Health and Disease. Philadephia, Lea and Febiger ; pp533-556

Garrow JS and Webster J (1985). Quetelet's index (W/H $\left.{ }^{2}\right)$ as a measure of fatness. Intl.J. Obesity 9: 147-153

Goldstein DJ (1992). Beneficial health effects of modest weight loss. Intl. J of Obes 16: 379-45

James WPT; Maseie - Taylor CGN; Morgan NS; Bistrian BR ; Shelly PS and Ferro - Luzzi A (1994).The value of MUAC in assessing chronic energy deficiency in Third World adults. Eur. J.Clin Nutr. 48: 883 894

Manson JE; Willettt WC; Stampfer MJ ; Colditz GA; H;Hunter DJ; Hankinson SE; Hennekens CH and Speizer FE (1995). Body weight and mortality among women. New England Journal of Medicine; 333,677-685.

Marks GC; Habicht JP and Mueller WH (1985) Reliability, dependability and precision of anthropometric measurements: the second National Health and Nutrition Execution Survey, 1975- 1980. Am J. Epidemiol; 30: $57-87$.

Norgan NG (1990), Body mass index and body energy stores in developing countries. Eur. J Clin Nutr;44:79-

Moore KL and Dalley AF (1990).Clinically oriented anatomy. Fourth edition. Kelly P (ed) Baltmore, USA, Lippincott Williams and Wilkins;pp 1-1111.

Rissanen A; Helovaara M; Knekt P; Aromaa A; Reunanen A and Maatela J. (1989). Weight and mortality in finnish men. J. Clin Epidemiol; 42: 781-89.

Seireg M (1989) Food and Nutrition surveys. Managua, Nicaragua: UNICEF/PQAN .

Rabe B; Thamrin MH; Gross R; Solomons NW and Schultink W(1996). Body mass index of the elderly derived from height and from armspan. Asia pacific $\mathrm{J}$ of Clin Nutr.5(2): $79-83$.

Schmidt R; Dunler F; Cruz C; Lubkowski T and Kilates $\mathbf{C}$ (1992). Improved nutritional follow up of peritoneal dialysis patients with bioelectrical impedance. Adv Perit Dial; 8: 157- 159.

Solomons NW; Mazariegos M and Mendoza 1 (1992).Uses of anthropometry in the elderly in the field setting with notes on screening in developing country. Asia Pacific $\mathrm{J}$ of Clin Nutr 2: $5-23$.

Steele MF and Maltox JW (1987). Short Report: Correlation of armspan and height in young women of two 
races. Ann. Human Biol. 14: 445-447.

Strickland SS and Ulijaszek SJ \{1993\}. Body masss index, ageing and different reported mortality in rural Sarawak. Eur J Clin Nutr 49:9-19

Tanphaichitr V and Leehagul PC (1995) Need and opportunity in assessing body composition. Asia Pacific. J. of Clin Nutr. 4(1): 23-24

Tayie FAK ;Agyekun S; Owusu - Ahenkora M;Busolo D ; Adjetey - Sorsey E; Armah E and Imaya E \{2003\}. Armspan and halfspan as alternatives for height in adults: a sample study from Ghana. African $\mathrm{J}$ of Food Agric and Development 3(2).

Taylor OG; Oyediran OABO; Bamgboye AE; Afolabi BM and Osuntokun BO (1996). Profiles of some risks factors for coronary heart disease in a developing country. Nigeria. Af. J. Med med Sci. 28: 341 - 46.

Torres LA Martinez FE and Manco JC (2003). Correlation between standing height, and armspan as index pulmonary function in 6-10 year - old children. Pediatr Pulmonol 36 (3):
$202-8$.

Wang J; Thornston JC; - Russell M; Burastero S; Heymsfield S and Pierson RN (Jr) (1994). Asians have lower body mass index (GMI) but higher percent body fat that do whites: comparison of anthropometric measurement. Am.J. Clin. Nutr. 60:23-28.

WHO (1990) Diet nutrition and prevention of chronic disease. Report of a WHO Group Technical Report Series 797.

WHO (1995). Physical status: the use and interpretation of anthropometrics. Report of a WHO Expert CommitteeTechnical Report Series No 854, Geneva,.

Whiteney EN; Cataldo CB and Rolfes SR (1998). Understanding Normal and Clinical Nutrition. Fifth Edition. Lewis P (ed) Wadsworth Publishing Company, California, USA; pp $1-961$.

Womersly J and Durnin JVGA (1972). A comparison of the skinfold method with extent of overweight and various weightheight relationship in the assessment of obesity. J Chronic Dis: $25,329-43$. 